Limnol. Rev. (2014) 14,1: 33-43

DOI 10.2478/limre-2014-0004

\title{
Changing the geometry of basins and water resources of Lakes Gopło and Ostrowskie under the influence of anthropopressure
}

\author{
Adam Piasecki, Rajmund Skowron \\ Department of Hydrology and Water Management, Nicolaus Copernicus University, Lwowska 1, 87-100 Toruń, Poland, e-mail: piasec- \\ ki@doktorant.umk.pl (corresponding author), rskowron@umk.pl
}

\begin{abstract}
The paper presents the changes that have occurred in the morphometry of Lakes Gopło and Ostrowskie, which are located in central Poland. The analysis covered the period characterised by increased human interference into the water cycle, which has been taking place continually since the mid-eighteenth century. On the basis of available cartographic materials (aerial photographs, topographic maps, bathymetric charts of the lakes) and the authors' own field measurements digital terrain models were developed for the immediate environment of the surveyed lakes. These models, in turn, were used for measuring basic parameters characterising the external dimensions of the lakes (surface area, length and maximum width, shoreline length) and their underwater relief (volume, maximum and average depth). In addition, the selected indicators of the shape and form of the lake basins were determined. The results showed a drastic reduction of water resources of the two lakes. The basin of Lake Gopło covers only the deepest parts of the former reservoir, accounting for only $23.3 \%$ of the lake before 1772 , and $32.5 \%$ of its former volume. In the case of Lake Ostrowskie the surface area and volume decreased, respectively, by 23.5\% (74.9 ha) and 21.3\% (6 $\left.695000 \mathrm{~m}^{3}\right)$. Such large changes in surface area and volume of both lakes have contributed to significant changes in other morphometric parameters and indicators. In particular, significant changes were observed in relation to such morphometric characteristics as length and maximum width, as well as average and maximum depth.
\end{abstract}

Key words: cartographic analysis, transformation of the water cycle, disappearance of lakes, lake morphometry, water resources

\section{Introduction}

The evolution of glacial lake basins began with the end of the melting dead ice blocks, which for most of lakes in Poland took place in Alleröd, rarely in Bölling. The transformation of lake basins from their emergence to the present day is characterised by major changes which proceeded in stages (Stasiak 1963; Gołębiewski 1976). The two main factors behind these changes were the fluctuations in the water level of lakes caused by climate change (lake transgression and regression), and filling lake basins with autogenic (biogenic) and allogeneic (terrigenic) sediments (Choiński et al. 2011). Originally these were long-term fluctuations, lasting hundreds and thousands of years. It is generally accepted that the average level of disappearance of lakes from the Weichselian Glaciation is about 65-75\% (Kalinowska 1961).
The second type of change refers to the last 250 years. Besides natural factors, these transformation factors are primarily associated with the human economic activities. These activities resulted in significant morphometric changes of lakes and their consequences were observed over a relatively short period of time (seasonal or annual changes or over several years). In particular, they are clearly associated with the beginning of the exploitation of minerals (Kędziora 2008; Marszelewski and Radomski 2008; Marszelewski and Skowron 2011) and drainage works carried out for the purposes of agriculture (Kaniecki 1997).

This paper is an attempt to answer the question of how significant the changes are in the morphometry of Lakes Gopło and Ostrowskie, in central Poland, in terms of the water cycle, in the period of increased human interference which has been taking place continuously since the mid-eighteenth century. 


\section{Research methods}

Based on the available cartographic materials (aerial photographs, topographic maps, bathymetric charts and archival records) and own field measurements, the changes in the lakes' surface area and volume were determined. The study also specifies some other basic surface parameters of the lakes (maximum length and width, the length of the shoreline), their sub-aqueous parameters (maximum and average depth), as well as selected morphometric ratios (compactness ratio, lake basin's stability index). Morphometric parameters and ratios were determined according to the methodology presented in the papers by Kerekes (1977) and Choiński (2007). The bases for the calculation of all the morphometric characteristics were digital terrain models of the studied lakes (Fig. 1). These models were prepared using the ArcGis 9.3 software.

A digital terrain model, including the lake basin and its immediate surroundings, was based on topographic maps and bathymetric charts made by the Inland Fisheries Institute (Instytut Rybactwa Sródlądowego - IRS) in Olsztyn (IRS 1953, 1960). Bathymetric charts were referred to the shoreline that is shown in the topographic map at a scale of 1:10 000 (from the early 1980s). Due to the fact that the shoreline in the bathymetric chart was mapped in an approximate way (the charts were made in winter, when setting the water-land border is difficult) the course of the shoreline was taken from a topographic map (scale 1:10 000). Assuming that the position of the isobaths in relation to the shoreline at the bathymetric chart is mapped correctly, they were digitised. Then, each isobath was assigned appropriate values of altitude. In order to illustrate the area beyond the current shoreline the terrain shown in the topographic map at a scale of 1:10 000 was used, from which epilittoral was vectorised.

\section{Study area}

Lakes Gopło and Ostrowskie are located in the eastern part of the Gniezno Lake District, which constitutes part of the macro-region of the Wielkopolskie Lake District. Hydrographically they are located in the catchment of the River Eastern Noteć (Fig. 2). The distance between the lakes in a straight line is about $11 \mathrm{~km}$. Back in the 1980s they were connected by the Ostrowo-Gopło Canal, where an excess of water (especially in spring) was directed to Lake Gopło (Mrózek
1965). Their catchment area, generally shaped during the Poznan Phase of the Weichselian Glaciation, has diverse relief showing a slight slope towards the channel of Lake Gopło. The total surface area of the catchment of both lakes (by the mouth of the Pieranie Canal) is $1426.3 \mathrm{~km}^{2}$.

The basin of Lake Gopło has an elongated shape whose long axis goes in the direction NNW-SSE. It consists of two clearly distinguishable parts. The main body of water is the channel part which shows a large diversity of bottom relief (it contains five depths separated by thresholds) and a length of $25 \mathrm{~km}$. From the west the channel part links with the so-called bay basin where the depth increases towards the north. The two basins are separated by the Potrzymiech Peninsula (Fig. 3).

Surface area of Lake Gopło is significant (2121.5 ha; Choiński 2006) and by its size it is the ninth lake in Poland. It is also a very shallow lake, as the average depth is only $3.6 \mathrm{~m}$ (the maximum is $16.6 \mathrm{~m}$ ). As a result, the volume of water stored in this lake is relatively small (78 $497 \mathrm{~m}^{3}$, IRS 1953). Thanks to numerous bays, peninsulas and islands the lake has a high rate of shoreline development (5.55). The shallow-water nature of the lake is underlined by the fact that the surface area enclosed between the shoreline and isobath $2 \mathrm{~m}$ (littoral zone) covers up $48.7 \%$ of the total surface area of the lake. Deep water zone (below the isobaths $15 \mathrm{~m}$ ) takes only $0.1 \%$ of the lake's area. The most extensive shallows are found in the southern part of the bay part and to the south and north of the town of Kruszwica. The ancient lake bed and the slopes of its basin, now exposed and in many parts transformed into arable land and meadows, have been gradually remodelled as a result of agricultural denudation and natural slope processes (Sinkiewicz 1989).

According to the Inland Fisheries Institute in Olsztyn the surface area of Lake Ostrowskie is 314.5 ha, while according to the Directory of Polish Lakes (Choiński 2006) - 272.0 hectares. The latter value, however, refers to the result of the planimetry of the lake surface in a topographic map at a scale of 1:50 000. The research carried out in 2009 using a geodetic GPS receiver (Leica GX1230 GG) gave a result of 242.0 hectares.

Currently, Lake Ostrowskie consists of two reservoirs connected through a channel which is 70 $\mathrm{m}$ long and 2-3 $\mathrm{m}$ wide. The western part has a narrow channel-like character (length of about $6.5 \mathrm{~km}$ and width up to $0.4 \mathrm{~km}$ ) with a sequence of succes- 


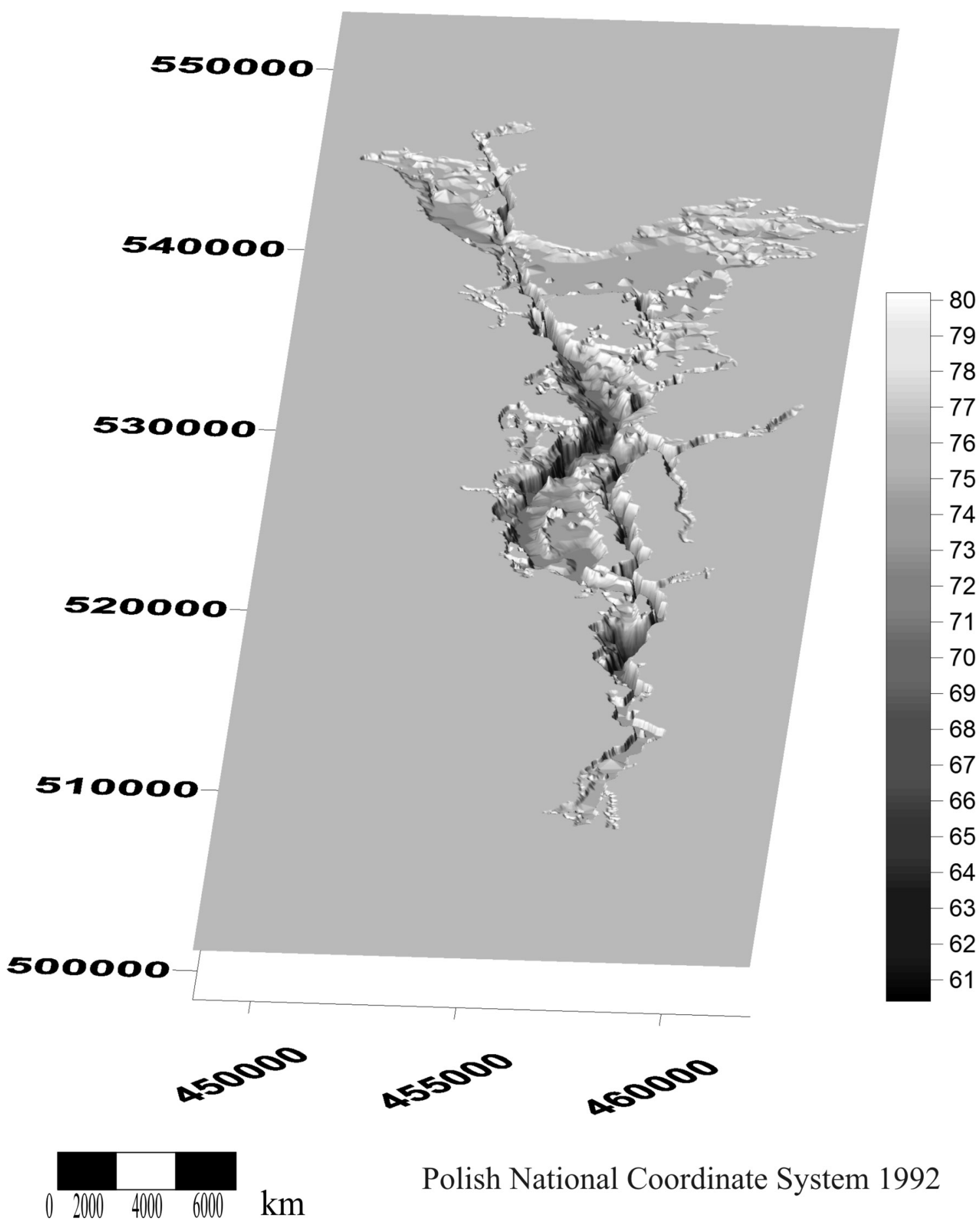

Fig. 1. Digital terrain model of the basin of Lake Gopło

sive depths (Fig. 3). However, the eastern part is a vast body of water of about $0.9 \mathrm{~km}$ in width, with a centric system of isobaths and a wide littoral zone (Kunz et al. 2010).

The analysed lakes are located in a region of relatively low precipitation. At the measurement station in Gniezno mean annual precipitation in the multi- annual period 1951-2006 was $514 \mathrm{~mm}$ and showed a significant variation in individual years. The highest precipitation was recorded in the years 1967 (789 $\mathrm{mm})$ and $1961(731 \mathrm{~mm})$. The lowest precipitation occurred in 1982, 1959 and 1989 and amounted, respectively, to 298, 340 and $342 \mathrm{~mm}$. For the analysed multi-annual period there was a slight upward trend 




in precipitation total $\left(1.07 \mathrm{~mm} \mathrm{yr}^{-1}\right)$. The last few years of that multi-annual period of time, however, showed an opposite trend, i.e. a decrease in precipitation totals (Marszelewski and Skowron 2011; Marszelewski et al. 2011).

In terms of the intensity of water exchange the lakes represent different hydrological types. Lake Gopło is a reservoir with characteristics typical of lakes with an average hydrological activity, while Lake Ostrowskie represents a passive type. In the case of Lake Gopło this feature stems from a high rate of horizontal water exchange $\left(\mathrm{FR}=1.25 \mathrm{yr}^{-1}\right)$ and a large an- nual range of the water levels. However, the passive hydrological nature of Lake Ostrowskie is mainly due to the low rate of horizontal exchange of water ( $F R=$ $0.29 \mathrm{yr}^{-1}$ ) until 2003 (now it is a no-through lake).

Observations of water levels in Lake Gopło have been conducted in Kruszwica since 1887. They are one of the longest observational series in Poland (Fig. 4). During the period of 1887-2010 the average water level in the lake was $231 \mathrm{~cm}$, which corresponds to a water level elevation of $76.82 \mathrm{~m}$ (Marszelewski and Skowron 2011). During this period the absolute range of water levels reached $273 \mathrm{~cm}$. 


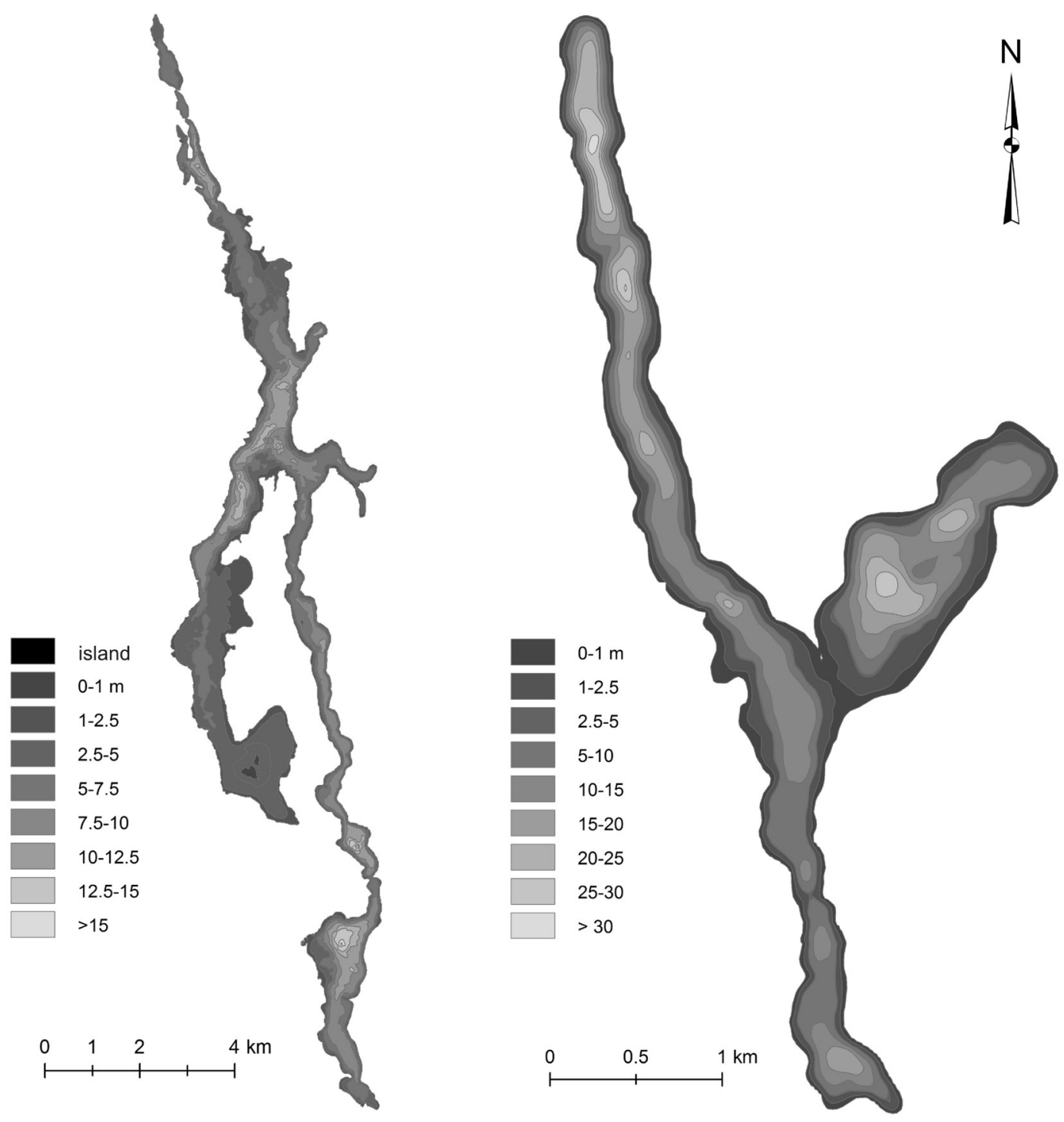

Fig. 3. Bathymetry of Lake Gopło (left) and Lake Ostrowskie

Measurements of water levels conducted on Lake Ostrowskie showed that in the years 1993-1998 the average water level was at an altitude of $97.45 \mathrm{~m}$, and was about 1.3-1.5 $\mathrm{m}$ lower than the level in the 1960s (Ilnicki 1996). Since 1999, the rise by about 0.6 $\mathrm{m}(98.03 \mathrm{~m})$ of the water level was observed in the lake, and after 2004 it was again reduced down to $97.01 \mathrm{~m}$. Large changes particularly occurred in 2010, when the water level dropped to the lowest in the history of the lake of $96.35 \mathrm{~m}$ (Fig. 5).

\section{Results}

The changes that have occurred in Lake Gopło over the last 240 years are a profound example of the human impact on the evolution of the water level in the lake (Table 1). After the analysis of topographic maps and available literature it was considered that the most likely maximum water level in Lake Gopło was at the elevation of approx. $80 \mathrm{~m}$. The surface area of the lake at that time stretched from Mątwy and Szymborze (Lake Szarlej) in the north, down to Lake Mileno in the south. The range of Lake Gopło at the 


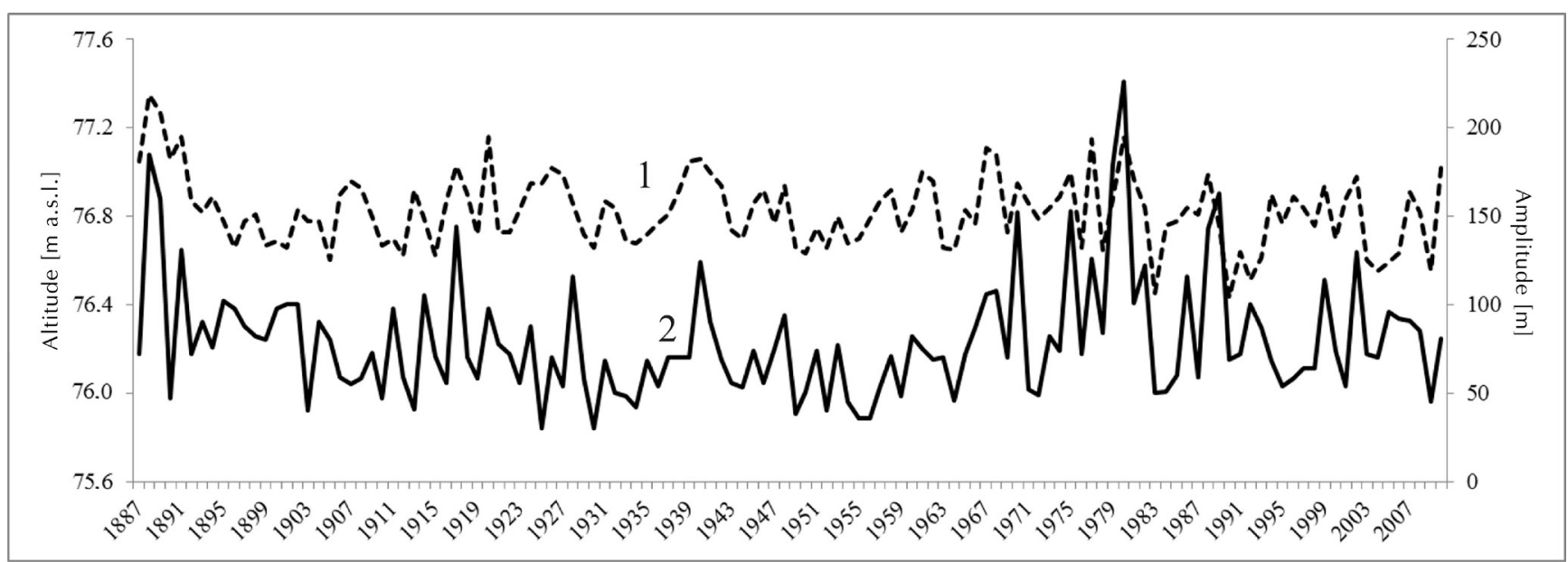

Fig. 4. Lake Gopło. Course of mean annual water levels (1) and annual range of water level (2) at the water gauge in Kruszwica: 18872010 (according to the IMGW data)



Fig. 5. Lake Ostrowskie. Course of mean annual water levels (1) and annual range of water level (2) (based on the KWB Konin data)

Table 1. Estimated changes of water level in Lake Gopło since reaching the level of the middle terrace (peat) to date by various authors (after Dorożyński and Skowron 2002)

\begin{tabular}{|c|c|c|}
\hline Period of time or year & Specification & $\begin{array}{l}\text { Water level } \\
\text { [m a.s.I.] }\end{array}$ \\
\hline $4200-1700 \mathrm{BC}$ & First settlement evidence in the vicinity of Kruszwica & 80.00 \\
\hline $650-400 \mathrm{BC}$ & Emergence of Rzępowski Peninsula & 77.00 \\
\hline approx. 1450 & Lake described by Długosz & 83.20 \\
\hline 1772 & Lake before the first regulatory works & 80.20 \\
\hline 1775 & $\begin{array}{l}\text { Completion of the Bydgoszcz Canal. As a result of the work carried out in the years } 1772-1774 \\
\text { the water table in the lake lowered by } 0.50 \mathrm{~m}\end{array}$ & 79.70 \\
\hline 1811 & Levelling measurements by Surowiecki & 79.80 \\
\hline 1860 & $\begin{array}{l}\text { Drainage works in the catchment of the upper Noteć in the years } 1857-1859 \text { reduced the water } \\
\text { level in the lake by } 1.38-1.40 \mathrm{~m}\end{array}$ & 78.30 \\
\hline $1879-1975$ & $\begin{array}{l}\text { Channelization of the upper Noteć in the years } 1870-1878 \text { resulted in a further reduction in the } \\
\text { water level by } 1.30 \mathrm{~m}\end{array}$ & 77.00 \\
\hline 1912 & Bathymetric measurements of Lake Gopło carried out by Schütze & 77.02 \\
\hline 1923 & Bathymetric measurements of Lake Gopło carried out by Sperczyński & 77.02 \\
\hline since 1975 & Regulation of the outflow at the weir in Pakość & 76.82 \\
\hline
\end{tabular}


level of the middle terrace lasted until the early nineteenth century (Mrózek 1965; Niewiarowski 1978). As a result of the regulatory activities conducted in the riverbed of the River Noteć in the years 1775-1878 and irrigation measures in its upper reaches, the water in the lake dropped by about $2.7 \mathrm{~m}$ (Table 1).

Lake Ostrowskie does not have as long series of observation of its water levels as Gopło. The specialist literature on this lake is also very poor and mainly focuses on the changes that have occurred in the lake over the past 20 years (Ilnicki 1996; Kędziora 2008; Marszelewski and Radomski 2008). The original surface area of the lake was based on the Topographische Karte (scale 1:25 000) of 1887. The water in Lake Ostrowskie was then at an altitude of $99.0 \mathrm{~m}$. In recent years, the level of the lake water was at a height of $96.5 \mathrm{~m}$.

The contemporary basin of Lake Gopło fills up only the deepest parts of the former reservoir, accounting for only $23.3 \%$ of the surface area before 1772 , and $32.5 \%$ of its former volume. Such a significant change in the two basic quantities describing the geometry of a lake basin must have altered other morphometric parameters. The length and the maximum width reduced their original size by nearly $50 \%$. However, the width of the lake decreased somewhat greater resulting in an increase of the elongation index up to 9.2. The shoreline decreased significantly (by $58 \%$ ) caus- ing a decline in the shoreline development by 0.83 . The number and surface area of islands decreased by, respectively, 241 and 1177.1 ha (97\%). The reason for this was the withdrawal of the lake from an area in its former eastern part. This area was the shallowest part of the former Lake Gopło characterised by numerous thresholds emerging in the form of islands. Significant changes occurred in the lake basin geometry, especially in the depth relations.

Lowering the water level by over 3 meters resulted in the disappearance of the wide littoral zone, and a simultaneous increase in the average depth by 0.9 $\mathrm{m}$. The result of these changes included the decrease in the index of basin permanence. According to Kerekes (1977), its value decreases with the ongoing process of the lake disappearance. This case study seems to confirm that. There was also a two-fold increase in an empirical depth index. High values of this index are characteristic of deep and compact lakes, but low for shallow lakes of large areas. In the case of Lake Gopło, despite the significant increase in the ratio up to the value of 0.21 , it remains very low. Changes in the geometry of the lake basin are also well illustrated by a relationship between its horizontal and vertical morphometric parameters, as expressed by the relative depth indicator. The decrease in its value from 4.17 to 1.16 indicates further shallowing of the lake basin (Table 2).

Table 2. Morphometric parameters of Lakes Gopło and Ostrowskie

\begin{tabular}{|c|c|c|c|c|c|}
\hline \multirow{3}{*}{ Parameters } & \multirow{3}{*}{ Symbol or formula } & \multirow{2}{*}{\multicolumn{2}{|c|}{$\begin{array}{c}\text { Lake Gopło } \\
\text { Water table elevation }\end{array}$}} & \multicolumn{2}{|c|}{ Lake Ostrowskie } \\
\hline & & & & Water table & elevation \\
\hline & & $80.00 \mathrm{~m}$ a.s.l. & $76.82 \mathrm{~m}$ a.s.I. & $99.00 \mathrm{~m}$ a.s.l. & $96.50 \mathrm{~m}$ a.s.l. \\
\hline Surface area [ha] & A & 9245.2 & 2163.9 & 318.4 & 243.5 \\
\hline Surface area of islands [ha] & $A_{w}$ & 1209.9 & 32.8 & - & - \\
\hline Volume $\left[\mathrm{dam}^{3}\right]$ & V & 235845.8 & 76739.9 & 31430 & 24735 \\
\hline Maximum length [m] & $\mathrm{L}_{\max }$ & 41243 & 25746 & 6950 & 6793 \\
\hline Maximum width [m] & $\mathrm{W}_{\max }$ & 5431 & 2783 & 962 & 469 \\
\hline Extension & $\lambda=\mathrm{L}_{\max } / \mathrm{W}_{\max }$ & 7.6 & 9.2 & 7.2 & 14.5 \\
\hline Mean width $[\mathrm{m}]$ & $\mathrm{W}_{\text {mean }}=\mathrm{A} / \mathrm{L}_{\max }$ & 2241.6 & 840.5 & 458.1 & 358.5 \\
\hline Shoreline length [km] & SL & 221.14 & 93.24 & 20.6 & 19.9 \\
\hline Development of shoreline & $\mathrm{K}=\mathrm{SL} / 2(\pi \mathrm{A})^{0.5}$ & 6.49 & 5.66 & 3.25 & 3.59 \\
\hline Maximum depth [m] & $D_{\max }$ & 19.6 & 16.6 & 35,2 & 32,6 \\
\hline Mean depth $[\mathrm{m}]$ & $\mathrm{D}_{\text {mean }}=\mathrm{V} / \mathrm{A}$ & 2.6 & 3.5 & 9.87 & 10.16 \\
\hline Depth indicator & $\mathrm{W}_{\mathrm{g}}=\mathrm{D}_{\text {mean }} / \mathrm{D}_{\text {max }}$ & 0.13 & 0.21 & 0.28 & 0.31 \\
\hline Index of basin permanence & $\mathrm{T}=\mathrm{V} / \mathrm{L}$ & 1066.5 & 823 & 1525.7 & 1242.9 \\
\hline Filatova's depth index & $\mathrm{C}=\mathrm{D}_{\text {max }} / \mathrm{W}_{\text {mean }}$ & 0.009 & 0.02 & 0.08 & 0.09 \\
\hline Relative index of depth & $\mathrm{C}_{\mathrm{R}}=\mathrm{D}_{\text {mean }} / \mathrm{W}_{\text {mean }}$ & 1.16 & 4.17 & 21.54 & 28.33 \\
\hline
\end{tabular}


Similarly to Lake Gopło, Lake Ostrowskie has been significantly transformed over the past 100 years. Its area as well as its volume decreased, respectively, by $23.5 \%$ (74.9 ha) and 21.3\% (6 $\left.695000 \mathrm{~m}^{3}\right)$. This affected the values of all other morphometric parameters and indicators, especially those that are used to calculate the mentioned parameters. It should be emphasised a decrease in the values of parameters characterising the surface of the lake, including the shoreline length, maximum length of the lake and the average width, were rather slight. The reason for this is the shape of the lake basin, which in the case of this lake is clearly tapered. This is confirmed by the obtained value of the depth index (approx. 0.3). Also, the empirical indicators of the relative depth of Filatova and the depth index show the lake is deep and compact. In the case of the latter ratio a significant change of its value (from 21.54 to 28.33 ) was observed. It was the result of a decrease in the average width by about $100 \mathrm{~m}$ due to the reduction of water level in the lake. To a very large extent, the maximum width was also reduced, which was the result of the division of Lake Ostrowskie into two water bodies. Moreover, it is worth mentioning that there was a significant reduction in the rate of the lake's basin sustainability (from 1525.7 to 1242.9). The decrease in this ratio indicates a progressive disappearance of the lake (Table 2).

The data from a weir in Pakość (Table 3) indicate that for Lake Gopło the differences between the surface area and volume between the maximum and minimum levels of damming are, respectively, 716.4 ha and $31393500 \mathrm{~m}^{3}$. The change in the surface and volume of the lake between high big water (WWW) and the lowest low water (NNW) in the period of instrumental measurements (1887-2010) was 3666.5 ha and $79073900 \mathrm{~m}^{3}$.
In the case of Lake Ostrowskie the volume and surface area difference between the WWW and NNW states was $6956500 \mathrm{~m}^{3}$ and 74.47 ha. Mean annual range of water levels in the years 1992-2010 was 20 $\mathrm{cm}$. The volume of the water layer specified by the mean annual range of water levels reached $541800 \mathrm{~m}^{3}$.

\section{Discussion of the results}

Measurable effects of decreasing water level in the lakes are changes in their surface areas as well as morphometric characteristics related to their basins. The analysis of digital terrain model including the lake basins and their epilittoral zones showed significant changes in both the surface area and volume of both lakes during the studied period, as well as significant differences in the results obtained from earlier studies of this type (Dorożyński and Skowron 2002).

The results of surface changes and the volume of Lakes Gopło and Ostrowskie at the extreme levels of the water table showed very large disparities. The surface area of Lake Gopło at the lowest low water (NNW) in relation to the surface area of the lake observed at the high big water levels (WWW) decreases by $66 \%$ and the volume by $59 \%$. These changes are more than two times higher than in the case of Lake Ostrowskie, for which they are, respectively, 24 and $23 \%$. These differing results are due to the above mentioned difference in the shapes of lake basins. In Lake Ostrowskie the basin is conical, and in Lake Gopło it has a strongly concave shape. As a result, the changes in the surface area and volume of Lake Ostrowskie are much smaller, even though the lake shows a similar absolute range of water levels to those in Lake Gopło (Lake Ostrowskie $2.2 \mathrm{~m}$, Lake Gopło $2.7 \mathrm{~m}$ ). The shape of the lake basin and its shallowness make Lake Gopło

Table 3. Changes in the area and volume of Lakes Gopło and Ostrowskie at different water levels according to the digital terrain model

\begin{tabular}{|c|c|c|c|c|c|c|}
\hline \multirow[b]{2}{*}{$\begin{array}{l}\text { Characteristic water table } \\
\text { levels in } \mathrm{m}\end{array}$} & \multicolumn{3}{|c|}{ Lake Gopło } & \multicolumn{3}{|c|}{ Lake Ostrowskie } \\
\hline & 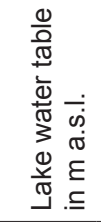 & 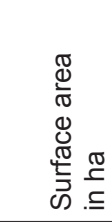 & 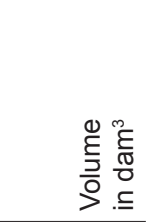 &  & 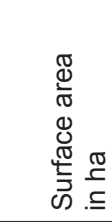 & 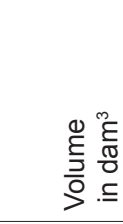 \\
\hline WWW & 78.75 & 5574.2 & 134780.1 & 98.56 & 303. 12 & 29956.9 \\
\hline Maximum damming & 77.31 & 2562.5 & 84284.2 & - & - & - \\
\hline Mean level & 76.82 & 2163.9 & 76739.9 & 97.47 & 269.04 & 26890.5 \\
\hline NNW & 76.02 & 1907.7 & 55706.2 & 96.35 & 228.65 & 23000.4 \\
\hline Minimum damming & 75.87 & 1846.1 & 52890.8 & - & - & - \\
\hline
\end{tabular}


react much more strongly to rapid changes in water level than Lake Ostrowskie. Therefore it is more prone to degradation and vegetation succession.

Table 4 shows the values of the analysed parameters and morphometric indicators obtained for these lakes by other authors. A significant difference in results compared to those obtained in the present study (Table 2) is found in Dorożyński and Skowron (2002). It results from the use of different procedures. Dorożyński and Skowron (2002) determined the surface of Lake Gopło graphically (by counting the number of squares on graph paper), while linear parameters were measured using a curvimeter and dividing compass. Analysis of the lake's surface, using modern computer methods, allows the detection of an error in the calculation. The surface area given in the cited work is greatly exaggerated compared to the actual one. Additional analysis of the materials used in the work of these authors confirmed an error in the calculation referring to the surface area occupied by Lake Gopło at an elevation of $80 \mathrm{~m}$. A significant difference between the surface of the islands and the length of the shoreline may be explained by the use of different accuracy of the measurement material. In the cited paper the measurements were made using a topographic map at a scale of 1:50 000, and in this paper, on the other hand, a topographic map at a scale of 1:10 000 was used.

The results obtained from the bathymetric chart for Lake Gopło by the IRS are similar to the results obtained by the authors (Table 2). One difference is found in the determined surface area, though. The reason for this is, as already mentioned, low accuracy of the shoreline delimitation on the bathymetric charts (they were made in the winter, when setting the waterland border is inaccurate).

In the case of Lake Ostrowskie no significant differences of the results were found. Slight differences exist in relation to the IRS bathymetric chart, but this is mostly due to the already mentioned factors related to the accuracy of determination of the shoreline in winter.

\section{Conclusion}

The issue of changes in lake retention is a relatively new problem, which is very interesting not only because of the importance of water management, but also from a purely cognitive point of view. Lake water resources are not permanent, and their variation is

Table 4. Morphometric parameters of Lakes Gopło and Ostrowskie (according to the IRŚ, Kunz et al. 2010, supplemented by calculations by the authors)

\begin{tabular}{|c|c|c|c|c|c|}
\hline \multirow{3}{*}{ Parameters } & \multirow{3}{*}{$\begin{array}{l}\text { Symbol or } \\
\text { formula }\end{array}$} & \multirow{2}{*}{\multicolumn{2}{|c|}{$\begin{array}{c}\text { Lake Gopło } \\
\text { Water table elevation }\end{array}$}} & \multicolumn{2}{|c|}{ Lake Ostrowskie } \\
\hline & & & & \multicolumn{2}{|c|}{ Water table elevation } \\
\hline & & $\begin{array}{l}80.00 \text { m a.s.l. (Drożyński } \\
\text { and Skowron 2002) }\end{array}$ & $\begin{array}{l}77.00 \mathrm{~m} \text { a.s.I. } \\
\text { (IRŚ 1953) }\end{array}$ & $\begin{array}{c}96.40 \text { m a.s.l. (Kunz et } \\
\text { al. } 2010 \text { ) }\end{array}$ & $\begin{array}{l}98.90 \text { m a.s.I. } \\
\text { (IRŚ 1960) }\end{array}$ \\
\hline Surface area [ha] & A & 11244.0 & 2154.5 & 242.0 & 314.5 \\
\hline Surface area of islands [ha] & Aw & 709.6 & 25.5 & - & - \\
\hline Volume $\left[\mathrm{dam}^{3}\right]$ & V & 279479.0 & 78497.0 & 24545.6 & 31242.9 \\
\hline Maximum length [m] & Lmax & 41700 & 25000 & 6784 & 6800 \\
\hline Maximum width [m] & Wmax & 8200 & 2500 & 462 & 1080 \\
\hline Extension & $\lambda=\mathrm{Lmax} / \mathrm{Wmax}$ & 5.1 & 10.0 & 14.7 & 6.3 \\
\hline Mean width [m] & Wmean = A/Lmax & 2696 & 872 & 357 & 462 \\
\hline Shoreline length $[\mathrm{km}]$ & SL & 166.4 & 91.3 & 20.1 & 19.9 \\
\hline Development of shoreline & $\mathrm{K}=\mathrm{SL} / 2(\pi \mathrm{A})^{0.5}$ & 4.43 & 5.55 & 3.64 & 3.17 \\
\hline Maximum depth [m] & Dmax & 19.6 & 16.6 & 32.6 & 35.1 \\
\hline Mean depth [m] & Dmean=V/A & 2.5 & 3.6 & 10.14 & 9.93 \\
\hline Depth indicator & $\mathrm{Wg}=\mathrm{Dmean} / \mathrm{Dmax}$ & 0.13 & 0.22 & 0.31 & 0.28 \\
\hline Index of basin permanence & $\mathrm{T}=\mathrm{V} / \mathrm{L}$ & 1679.6 & 859.8 & 1221.2 & 1569.9 \\
\hline Filatova's depth index & $\mathrm{C}=\mathrm{Dmax} / \mathrm{Wmean}$ & 0.007 & 0.019 & 0.07 & 0.03 \\
\hline Relative depth & $\mathrm{CR}=$ Dmean $/$ Wmean & 0.93 & 4.19 & 28.5 & 21.9 \\
\hline
\end{tabular}


mainly due to the evolutionary change of lake basins as well as lowering water levels in lakes as a result of anthropogenic and natural factors. Significant hydrological changes in the analysed lakes occurred along with the intensification of the exploitation of mineral resources, especially those related to opencast lignite mining (Wachowiak 1980; Ilnicki 1996; Marszelewski and Skowron 2010, 2011; Marszelewski et al.. 2011; Skowron 2011).

The analysis of the available cartographic and remote sensing materials as well as surveying confirmed by earlier research carried out by other authors (e.g. Niewiarowski 1978; Ilnicki 1996; Kunz et al. 2010) that the water table elevation in many lakes in Poland has significantly decreased over two centuries. This also applies to lakes situated in the Gniezno Lake District, particularly Lakes Gopło and Ostrowskie.

The calculations, using a digital terrain model, showed that the surface area of Lake Gopło between the second half of the eighteenth century and the first decade of the twenty-first century (1772-2010) decreased from 9245.2 ha to 2163.9 ha, i.e. by $76.6 \%$. Lake Ostrowskie also reduced its surface area, but to a much lesser extent. In the years 1887-2010 the total decrease in its surface area amounted to 74.9 ha, i.e. $23.5 \%$. In parallel with the reduction of the surface area of the analysed lakes their water resources were also reduced. Lake Gopło reduced in volume by more than $67 \%$, while Lake Ostrowskie by $21 \%$. Lake Gopło showed a faster pace of decline. In terms of the rate of change of the surface area and volume per decade it was, respectively, 3.2 and $2.8 \%$ for Lake Gopło, and, respectively, 1.9 and $1.7 \%$ for Lake Ostrowskie.

The most visible change within the former Lake Gopło basin as well as the entire landscape of the area, is the emergence of separate lakes: Szarlej, Tryszczyn, Łunin, Gocanowskie and Mielno. Similar transformation was observed in the case of Lake Ostrowskie. A former Lake Ostrowskie, due to lowering the water table elevation by more than two meters, divided into two basins.

The analysis of changes in the morphometry of the selected lakes' basins pointed out how strongly they have been transformed. At the same time it allowed to compare and verify the results obtained with old, traditional methods. The use of modern computer methods enabled the authors to obtain accurate, precise results as well as their graphic visualisation.

\section{References}

Choiński A., 2006, Katalog jezior Polski (Catalogue of lakes in Poland), Wyd. Nauk. UAM Poznań, p.600 (in Polish).

Choiński A., 2007, Limnologia fizyczna Polski (Physical limnology of Poland), Poznań, Wyd. Nauk. UAM, Poznań, p. 547 (in Polish).

Choiński A., Ławniczak A., Ptak M., Sobkowiak L., 2011, Causes of lake area changes in Poland, J. Resour. Ecol. 2(2): 175-180.

Dorożyński R., Skowron R., 2002, Changes of the basin of Lake Gopło caused by melioration work in the $18^{\text {th }}$ and $19^{\text {th }}$ centuries, Limnol. Rev. 2: 93-102.

Gołębiewski R., 1976, Osady denne Jezior Raduńskich (Bottom sediments of the Raduńskie Lakes), GTN, Gdańsk, p. 89 (in Polish, English summary).

Ilnicki P., 1996, Wpływ drenażu odkrywek węgla brunatnego na walory rekreacyjne Pojezierza Gnieźnieńskiego (The influence of drainage in Mine of lignite on values the recreational Lake district Gnieźnieńskie), Aura 11: 10-12 (in Polish).

[IRS] Instytut Rybactwa Śródlądowego w Olsztynie, 1953, Mapa batymetryczna jeziora Gopło (Bathymetric map of Lake Gopło), IRS, Olsztyn.

[IRS] Instytut Rybactwa Śródlądowego w Olsztynie, 1960, Mapa batymetryczna jeziora Ostrowskiego (Bathymetric map of Lake Ostrowskie), IRS, Olsztyn.

Kalinowska K., 1961, Zanikanie jezior polodowcowych w Polsce (Disappearance of glacial lakes in Poland), Prz. Geogr. 33 (3): 511-518 (in Polish, English summary).

Kaniecki A., 1997, Wpływ XIX-wiecznych melioracji na zmiany poziomu wód (Influence of the XIX ${ }^{\text {th }}$ century meliorations on change of the level of waters), [in:] Choiński A. (ed.), Wpływ antropopresji na jeziora, UAM, Poznań-Bydgoszcz, 67-71(in Polish).

Kerekes J., 1977, The index of lake basin permanence, Int. Revue ges. Hydrobiol. 62: 291-293.

Kędziora A., 2008, Bilans wodny krajobrazu konińskich kopalni odkrywkowych w zmieniających się warunkach klimatycznych (Water balance of Konin strip mine landscape in changing climatic conditions), Rocz. Glebozn. 59(2) 104-118 (in Polish, English summary).

Kunz M., Skowron R., Skowroński Sz., 2010, Morphometry changes of Lake Ostrowskie (the Gniezno Lakeland) on the basis of cartographic, remote sensing and geodetic surveying, Limnol. Rev. 10(2): 77-85.

Marszelewski W., Ptak M., Skowron R., 2011, Antropogeniczne i naturalne uwarunkowania zaniku jezior na Pojezierzu Wielkopolsko-Kujawskim (Anthropogenic and natural conditionings of disappearance of lakes in the Wielkopolska-Kujawy Lakeland), Rocz. Glebozn. 62(2): 283-294 (in Polish, English summary).

Marszelewski W., Radomski B., 2008, Quantitative degradation of water resources of the lakes in the eastern part of the Gniezno Lakeland, [in:] Bajkiewicz-Grabowska E., Borowiak D. (eds) Anthropogenic and natural transformations of lakes. Vol. 2., KLUG-PTLim, Gdańsk: 119-124. 
Marszelewski W., Skowron R., 2010, Hydrografia i warunki hydrologiczne (Hydrography and hydrological conditions), [in:] Mocek A., Owczarzak W. (eds), Aktualny stan środowiska przyrodniczego terenów sąsiadujących z uruchamianą odkrywką węgla brunatnego Tomisławice jako efekt uwarunkowań hydrogeologicznych, klimatycznych i glebowych (Current state of the natural environment of areas surrounding the seting off Tomisławice open-pit mine as the result of the hydrogeologic, climatic and soil conditions) [typescript], KWB Konin S.A., Konin: 40-59 (in Polish).

Marszelewski W., Skowron R., 2011, Związki między odwodnieniem odkrywki „Tomisławice” a wybranymi elementami ustroju hydrologicznego jeziora Gopło (Relations between dewatering of the Tomisławice open-pit mine and the selected elements of the hydrological regime of Lake Gopło), Rocz. Glebozn. 62(2): 273-282 (in Polish, English summary).

Mrózek W., 1965, Charakterystyka środowiska geograficznego Kruszwicy i części zlewni jezioro Gopło (Characteristics of the geographical environment of Kruszwica and part of Lake Gopło basin), [in:] Grześkowiak J. (ed), Kruszwica - zarys monograficzny (Kruszwica - monographic outline), Wyd. TNT, Toruń: 7-64 (in Polish).

Niewiarowski W., 1978, Fluctuations of Water-level in the Gopło lake and Their reasons, Pol. Arch. Hydrob. 25: 301-306.
Pasławski Z., Błaszczyk B., 1970, Charakterystyka hydrologiczna i bilans wodny Jeziora Gopło (Hydrological characteristics and water balance of Lake Gopło), Prz. Geof. 15: 251-266 (in Polish, English summary).

Sinkiewicz M., 1989, Zmiany rzeźby terenu Pojezierza Kujawskiego pod wpływem procesów stokowych (Changes in Kujawskie Lake District's relief under the influence of slope processes), Studia Soc. Sci. Torun. 9C(6): 95(in Polish).

Skowron R., 2004, Description of lake basin in the light of selected morphometric indicators, Limnol. Rev. 4: 233240.

Skowron R., 2011, Zróżnicowanie i zmienność wybranych elementów reżimu termicznego $\mathrm{w}$ jeziorach na Niżu Polskim (The differentiation and the changeability of chosen of elements the thermal regime of water in lakes on Polish Lowland), Wyd. UMK, Toruń, p. 345 (in Polish, English summary).

Stasiak J., 1963, Historia jeziora Kruklin w świetle osadów strefy litoralnej (History of Kruklin Lake as revealed by the deposits of its littoral zone), Pr. Geogr. Inst. Geogr. PAN, 42: 1-94 (in Polish, English summary).

Wachowiak G., 1980, Potwierdzenie niskiego odpływu średniego w okolicach jeziora Gopło (Confirmation of low mean outflow in the surroundigns of Lake Gopło), Gaz. Obserw. IMGW 10(33): 13-16 (in Polish). 